\title{
Long-term Outcomes for Children with Early Language Problems: Beating the Odds
}

Samantha Parsons* and Ingrid Schoon

Institute of Education, University of London, London, UK

Robert Rush and James Law

Queen Margaret University, Edinburgh, UK

Using the 1970 British Cohort Study, this study examines factors promoting positive language development and subsequent successful education and employment transitions among children showing early receptive language problems (age 5). We find that 61 per cent of children with early receptive language problems develop into competent readers by age 10 . Factors promoting positive language development include parental support and more importantly a good school environment, characterised by only few children receiving remedial help. Post-16 education and employment experiences indicated competent reading to be associated with a less challenging journey into adulthood. Findings are discussed in terms of their policy implications. (C) 2009 The Author(s). Children \& Society (C) 2009 National Children's Bureau.

Keywords: literacy and language.

\section{Introduction}

A body of research using longitudinal British birth cohort data suggests children with poor vocabulary and literacy development are far more likely to experience social and economic disadvantage later on in life (Bynner and Steedman, 1995; Parsons and Bynner, 1998). Specific socioeconomic factors shown to be associated with the development of vocabulary and reading skills during childhood include parental education, timing of parenthood and family structure (Arriaga and others, 1998; Brooks-Gunn and Duncan, 1997; Feagans and Farran, 1982; Hoff, 2003; McLoyd, 1998; Weigel and others, 2006) as well as housing conditions, especially overcrowding (Duncan and Brooks-Gunn, 1997; Essen and others, 1978; Evans, 2006; Evans and others, 1998; Gottfried, 1984; Rutter and others, 1970). Furthermore, a child-centred literacy orientation, indicated for example by a family's ability and willingness to read to the child (High and others, 1999, 2000; Klass, 2002; Mendelsohn and others, 2001; Raikes and others, 2006), as well as pre-school attendance (Brooks, 2003; Sammons and others, 2004) have been shown to have a beneficial and supportive influence for positive language development.

Children with poor vocabulary and reading skills are at great risk of failing to attain a basic grasp of literacy in adulthood (Bynner and Steedman, 1995; Parsons and Bynner, 1998). Poor adult literacy, in turn, is linked to disadvantages in many aspects of adult life, including increased risk of unemployment and welfare dependency, low earnings, early parenting and ill health (Berlin and Sum, 1988; Bynner and Parsons, 2006; DeWalt and others, 2004; Grinyer, 2006; Parsons and Bynner, 2007). 
This study has two aims. First, we examine the social context in which competent reading develops among children identified with poor receptive language at age 5, identifying factors in the home and school environment that act as risk or protective factors for the development of competent reading skills during primary school. Secondly, we assess the post-16 education and employment profiles of children with poor vocabulary at age 5 , contrasting experiences of those children with early language problems who developed competent reading by age 10 versus those who did not.

Within a sample of children with early receptive language problems, we test the following assumptions:

- The likelihood of competent reading by age 10 is increased for children who had parents with some kind of extended education or formal qualifications;

- The likelihood of competent reading at age 10 is increased for children who grew up in relatively privileged economic circumstances,

- The likelihood of competent reading at age 10 is increased for children experiencing a supportive home education (i.e. parents reading to the child, supporting education);

- The likelihood of competent reading at age 10 is increased for children who attend a primary school in a good socioeconomic catchment area;

- A stimulating early literacy environment moderates the negative impact of socioeconomic disadvantage in the home or school environment on competent reading.

- The long-term developmental outcomes for children who escaped a trajectory of poor language skills are better than for those who failed to develop competent reading by age 10 .

\section{Methods}

\section{Data}

The 1970 British Cohort Study (BCS70) is an ongoing longitudinal study that takes as its subjects all 17196 children born in Great Britain in one week in 1970 (Elliott and Shepherd, 2006). Six follow-up studies have monitored cohort member's physical, educational and social development and transitions to adult life. These studies were conducted in 1975 (age 5), 1980 (age 10), 1986 (age 16), 1996 (age 26), 1999-2000 (age 30) and in 2004 (age 34).

The present analyses make use of data from all sweeps from 1970 up to 2004. At age 5, information was collected on 13135 children with boys making up 51.8 per cent of all children. In 2004, the sample size was 9665 - 56 per cent of the original birth cohort and 74 per cent of the first (age 5) follow-up.

\section{Measures}

\section{Identification of receptive language at age 5}

Development and understanding of a child's (English) vocabulary at age 5 was assessed using the English Picture Vocabulary Test (EPVT), an adaptation of the American Peabody Picture Vocabulary Test (PPVT) (Brimer and Dunn, 1962). The test has a good reliability of 0.96 (Osborn and others, 1984). It consists of 56 sets of four different pictures. The child is asked to indicate the picture that corresponds to a given word. The test proceeds with words 
of increasing difficulty, until the child made five mistakes in a run of eight consecutive items. Children with 'poor' vocabulary were identified by scores at least 1 standard deviation below the average performance score.

\section{Reading skills at age 10}

Reading comprehension was assessed by The Shortened Edinburgh Reading Test at age 10 (Hodder and Stoughton, 1979). Children were asked to complete a variety of tasks over 66 items, including selecting the incorrect word in a sentence, matching answers to questions, extracting information from a picture, understanding the meaning of words, putting sentences in the correct order, etc. We identified 'poor' readers as children with scores at least 1 standard deviation below the average population performance score. All others were classified as 'competent' readers.

\section{Sample}

The EPVT was carried out on English-speaking children only, and we further restricted our sample to children where English was the primary language spoken at home. Our initial sample comprised 11349 children (all white British/European) who completed the EPVT at age 5. Of these, 15 per cent were identified with poor vocabulary $(n=1674)$. Among this group of children, 73 per cent $(n=1230)$ completed the reading test at age 10 . This study concentrates on this sample of 1230 children throughout, although there is further sample attrition due to responses missing for particular items used in the multivariate analysis linking experiences between ages 5 and 34 .

Assessment of response bias suggests that the overall profile of the cohort remains remarkably similar across surveys. The sample is representative, in most respects, of the general UK population of that age, although there is a trend towards under-representation of males and those less educationally advantaged (Elliott and Shepherd, 2006).

Encouragingly, 61 per cent of children with poor vocabulary at age 5 demonstrated competent reading skills at age 10 . However, 39 per cent were identified as poor readers at age 10. More girls than boys had been identified with poor receptive vocabulary at age 5 (17\% girls [ $n=695], 12 \%$ boys $[n=535])$, but more girls were competent readers at age 10 (65-54\% of boys). These results appear counterintuitive as it is often assumed that girls have better verbal skills than boys. However, there is some evidence to suggest that the relationship between gender and language may be clearer for expressive language skills and literacy than it is for receptive language (Hopman and others, 1988, Yamamoto 1990). Indeed it is possible that, in some circumstances, the conventional relationship may be reversed, i.e. favouring boys when using the PPVT and its English equivalent, the EPVT (Brimer and Dunn, 1962).

\section{Results}

Table 1 gives the descriptive statistics for the variables included in the models, and enables the comparison of early home environment, family life and school characteristics of children with poor receptive language skill at age 5, differentiating between those identified as competent versus poor readers at age 10 . Statistical comparisons of rates with $\chi^{2}$-tests at the $0.001,0.01$ and 0.05 were made. Given the bias in the data towards the better educated, it is 
Table 1: Early home life and school characteristics among children with poor vocabulary at age 5 who were competent versus poor readers at age 10

\begin{tabular}{|c|c|c|c|c|}
\hline & $\begin{array}{l}\text { Competent } \\
\text { readers } \%\end{array}$ & $\begin{array}{l}\text { Poor } \\
\text { readers \% }\end{array}$ & $\begin{array}{l}\text { Overall } \\
\%\end{array}$ & $\begin{array}{l}N \\
(100 \%)\end{array}$ \\
\hline \multicolumn{5}{|l|}{ Parental characteristics } \\
\hline Mother had first child age 20+ & $76^{* *}$ & 67 & 73 & 1218 \\
\hline Mother had extended education & $23^{* * *}$ & 12 & 18 & 1220 \\
\hline Father had extended education & $22^{* * *}$ & 10 & 17 & 1185 \\
\hline Mother had formal qualifications & $33^{* * *}$ & 15 & 26 & 1176 \\
\hline Father had formal qualifications & $40^{* * * *}$ & 23 & 33 & 1084 \\
\hline Father in unskilled/semi-skilled manual job & $32^{*}$ & 38 & 35 & 1203 \\
\hline \multicolumn{5}{|l|}{ Housing conditions } \\
\hline Family size <6 (5) & $78^{* * * *}$ & 68 & 74 & 1227 \\
\hline Home owner (5) & $43^{* * *}$ & 28 & 37 & 1227 \\
\hline$<1$ person per room in home (5) & $47^{* *}$ & 37 & 43 & 1210 \\
\hline \multicolumn{5}{|l|}{ Early education environment } \\
\hline Child attended pre-school (5) & $66^{* * * *}$ & 54 & 61 & 1181 \\
\hline Parent(s) read to child every day (5) & $28^{* * * *}$ & 18 & 24 & 1151 \\
\hline Parent a poor reader (5) & $5^{* * *}$ & 12 & 8 & 1113 \\
\hline Sibling a poor reader $(5)$ & $7^{* * *}$ & 14 & 10 & 1028 \\
\hline Mother 'very interested' in child's education ${ }^{a}(10)$ & $41^{* * *}$ & 19 & 33 & 1178 \\
\hline Father 'very interested' in child's education ${ }^{\mathrm{a}}(10)$ & $29^{* * * *}$ & 12 & 22 & 1076 \\
\hline Parents want post-16 education for child (10) & $48^{* * *}$ & 21 & 38 & 1118 \\
\hline \multicolumn{5}{|l|}{ Primary-school characteristics } \\
\hline $\begin{array}{l}\text { High \% children in school with very low/below } \\
\text { average academic ability }{ }^{b}\end{array}$ & $14^{* * * *}$ & 24 & 18 & 1158 \\
\hline $\begin{array}{l}\text { High \% fathers of children in school in semi } \\
\text { skilled manual jobs }{ }^{b}\end{array}$ & $23^{* * * *}$ & 35 & 28 & 1158 \\
\hline $6+$ children with remedial reading help & $26^{* * * *}$ & 41 & 32 & 1172 \\
\hline High $\%$ council houses in school catchment area ${ }^{b}$ & $30^{\mathrm{ns}}$ & 34 & 32 & 1175 \\
\hline
\end{tabular}

Statistical significance at ${ }^{* * *} P<0.001,{ }^{* *} P<0.01,{ }^{*} P<0.05,{ }^{\text {ns }}$ not significant.

${ }^{\mathrm{a}}$ Teacher rated.

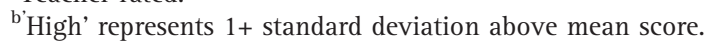

the poor readers who are the less likely to have been part of the survey at ages 5 and 10 , which means that results are likely to underestimate differences between competent and poor readers.

\section{Early home environment and family life}

Children with early receptive language problems who developed competent reading skills by age 10 grew up in a less disadvantaged family background and home environment than children with early language problems who did not develop competent reading by age 10 . More parents of children who became competent readers by age 10 had some extended education and qualifications. Competent readers were more likely to have grown up in an owner-occupied and not overcrowded home at age 5 and had not received free school meals at age 10 . Perhaps of most concern for policy makers is that more of the competent readers had attended some kind of pre-school, and that they had parents who were more likely to have read to them (at age 5), who showed interest in their child's education (at age 10) and aspired for their child to continue in full-time education post-16 (at age 10). Poor readers were more likely to have a parent or sibling who also had reading difficulties, highlighting the intergenerational transfer of skills - or a lack of skills - within families (De Coulon and others, 2008). 


\section{Primary-school characteristics}

At age 10 , the majority of children with poor vocabulary at age 5 went to a state-maintained primary school, with minimal differences between competent and poor readers. However, those who became competent readers were less likely to have been in a school where a high ${ }^{1}$ percentage of students' fathers worked in low-skilled manual work (23-35\%) and where a high percentage of fellow students were graded by their teacher as having 'low' or 'below average' academic ability (14-24\%). They were also less likely to be in a class where $\operatorname{six}^{2}$ or more children received remedial help with reading (26\% to $41 \%)$. There was no difference in the tenure of housing in the catchment area of schools.

\section{Predicting competent reading at age 10 among children with poor vocabulary at age 5}

We ran a series of logistic regression analyses to ascertain which experiences in early childhood held most importance for gaining competent reading at age 10 among those who had a poor vocabulary at age 5. Results are based on 819 children (67\%) of our analytic sample, comprising those children with complete information on all measures included in the multivariate models. The results, presented as odds ratios, are given in Table 2. A coefficient greater than 1 indicates an increased likelihood of competent reading, and a coefficient smaller than 1 indicates a reduced likelihood. Poor readers at age 10 are used as the baseline, or reference category. All models are controlled for birth weight and gestation to adjust for associated medical conditions that might be causal to later vocabulary and reading development.

Model 1: controlling for parental characteristics present at birth.

Being a girl and having at least one parent with some formal qualifications significantly increased the likelihood of competent reading at age 10 .

\section{Model 2: controlling for housing and economic disadvantage in childhood.}

Living in a smaller household (less than six persons) and in an owner occupied home significantly increased the likelihood of competent reading at age 10. Receiving free school meals (a strong indicator of a family's financial situation) significantly decreased a child's chance of gaining competence in reading.

Model 3: controlling for educational support from parents.

Having parents who are 'very interested' in their child's education and who held aspirations for post-16 education significantly increased a child's likelihood of being a competent reader at age 10 .

Model 4: controlling for school characteristics.

Attending a school where a relatively high percentage of students were rated with 'low' or 'below average' academic ability and where a relatively high percentage of students' fathers worked in low-grade manual occupations significantly decreased a child's likelihood of competent reading at age 10 . Being in a class where six or more children received remedial reading help (the average was four among this group of children) also significantly decreased a child's chance of competent reading at age 10 . 


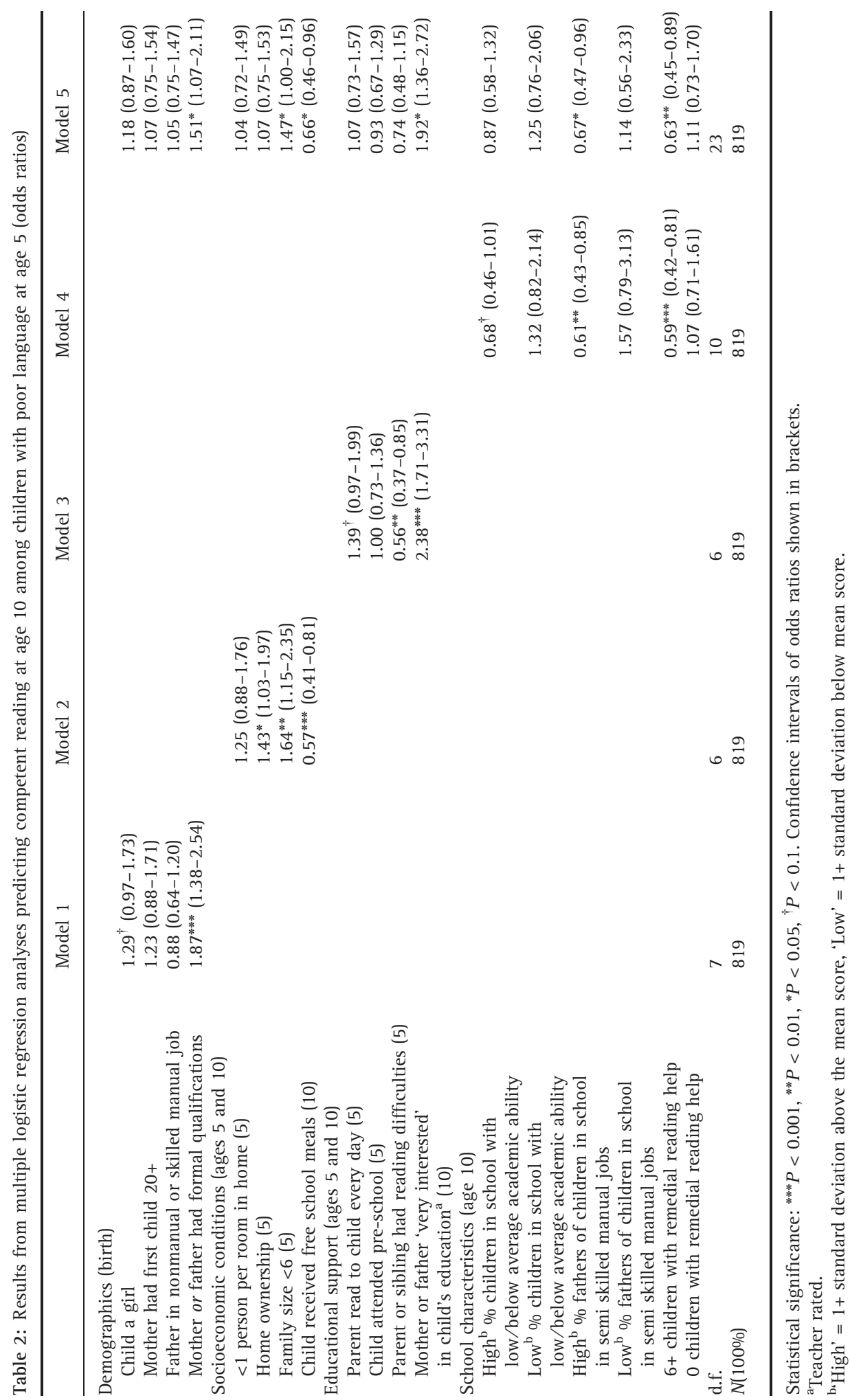




\section{Model 5: controlling for all measures.}

When controlling for all measures, the findings suggest that being part of a smaller household (less than six persons), having at least one parent with formal qualifications and parents who are 'very interested' in their child's education significantly increased a child's chance of competent reading by age 10. Free school meals, attending a school where a relatively high percentage of students' fathers worked in low-grade manual occupations and being in a class where six or more children received remedial reading help significantly decreased a child's chance of competent reading at age 10 .

The findings suggest that the course of development is not necessarily predetermined. The majority of children with poor receptive vocabulary at age 5 become competent readers by age 10 and thus escape a negative trajectory. Although the early disadvantage was relatively less stark for competent readers than poor readers, the multivariate regression models suggest that the likelihood of competent reading by age 10 among those with poor early vocabulary could be significantly increased by addressing poor housing and economic conditions, together with the ability of a child's family to provide a supportive home 'literacy' environment. However, it was the poor socioeconomic intake of a school, and a high number of children in a class receiving remedial education, which had a crucial impact on competent reading by age 10 . This finding might reflect that, up until age 5 , the family is the main environmental determinant of a child's development, but that by age 10 this has grown to include - and to a certain point been replaced by - the school environment.

\section{Post-16 experiences of cohort members with early receptive language problems}

The study now concentrates on post-16 education and employment outcomes, comparing the profiles of children with poor vocabulary at age 5 who were either competent or poor readers by age 10 . Once again statistical comparisons of rates with $\chi^{2}$-tests at the $0.001,0.01$ and 0.05 were made. Given the persistent gender differences in education and employment transitions, we present findings for men and women separately.

\section{Education, qualifications and basic literacy}

Table 3 shows that by the end of compulsory education in 1986, far fewer competent readers than poor readers had left full-time education (51-81\%) overall. Girls with competent reading were the least likely to have left school early. During their time at school, children with competent reading were around half as likely as poor readers to have truanted "most of the time' (4-11\% boys, 4-7\% girls). Among boys, 10 per cent of competent readers had been suspended compared to 26 per cent of poor readers. Four per cent of competent readers and 7 per cent of poor readers had been excluded. Among girls, competent readers were half as likely as poor readers to have been suspended from school (6\% to 13\%). Just 1 per cent of competent readers and 5 per cent of poor readers had been excluded.

By age 34, 16 per cent of all competent readers had degree-level qualification (13\% boys, 17\% girls), yet 13 per cent had no formal qualifications (19\% boys, 10\% girls): 33 per cent of poor readers (38\% boys, 30\% girls) had no qualifications, and only 3 per cent of poor readers held a degree (or equivalent). At a more basic level of attainment, many poor readers only had entry-level literacy skills at age 34 (below GCSE grade D-G). 
Table 3: Education characteristics of adults who had poor vocabulary at age 5 and were competent readers (CR) versus poor readers $(\mathrm{PR})$ at age 10

\begin{tabular}{|c|c|c|c|c|c|c|c|c|}
\hline & \multicolumn{4}{|l|}{ Men } & \multicolumn{4}{|c|}{ Women } \\
\hline & CR & $N$ & PR & $N$ & CR & $N$ & PR & $N$ \\
\hline \multicolumn{9}{|l|}{ Education, qualifications and basic literacy } \\
\hline$\%$ Left full-time education at $16(34)^{\mathrm{a}}$ & $58^{* * *}$ & 165 & 85 & 111 & $48^{* * * *}$ & 325 & 74 & 139 \\
\hline \% Truanted 'most of the time' (30) & $4^{*}$ & 190 & 11 & 140 & $4^{\mathrm{ns}}$ & 379 & 7 & 167 \\
\hline \% Suspended from school (30) & $10^{* * * *}$ & 190 & 26 & 140 & $6^{* * *}$ & 379 & 13 & 167 \\
\hline \% Excluded from school (30) & $4^{\mathrm{ns}}$ & 190 & 7 & 140 & $1^{*}$ & 379 & 5 & 167 \\
\hline \% No formal qualifications (34) & $19^{* * * *}$ & 165 & 38 & 111 & $10^{* * * *}$ & 325 & 30 & 139 \\
\hline \% Degree level qualification (34) & $13^{* *}$ & 165 & 3 & 111 & $17^{* * * *}$ & 325 & 4 & 139 \\
\hline \% Entry Level literacy (34) & $9^{* * * *}$ & 163 & 41 & 109 & $9^{* * * *}$ & 325 & 33 & 134 \\
\hline \% Level 2 (or higher) literacy (34) & $55^{* * * *}$ & 163 & 24 & 109 & $62^{* * * *}$ & 325 & 29 & 134 \\
\hline
\end{tabular}

Statistical significance: ${ }^{* * *} P<0.001,{ }^{* *} P<0.01,{ }^{*} P<0.05$, ${ }^{\text {ns }}$ not significant.

${ }^{\mathrm{a}}$ Age of data collection.

\section{Employment}

\section{Young men}

Nearly half of all boys with poor vocabulary at age 5 entered full-time employment at age 16 (1986). From this time to the end of 2003, the young men who were competent readers by age 10 had spent an average of 19 months more in full-time employment and 10 months more in full-time education compared to those with poor reading at age 10. Poor readers at age 10 had, on average, experienced nine months more unemployment and eight months more full-time government training (e.g. Youth Training Scheme straight from school). Figure 1(a) shows that in each year from age 16 (1986), a higher percentage of competent readers than poor readers had spent the majority of each 12-month period in employment. The 'gap' between these two groups was highest in the mid-1990s at the time of economic recession, i.e. when employers viewed those with fewer skills as more expendable, or they were in occupations offering least security.

At age 34 (2004), 46 per cent of competent readers held a nonmanual occupation and 16 per cent worked in partly or unskilled manual jobs. Figures for poor readers were 25 per cent and 31 per cent respectively. Average weekly net earnings for competent readers in full-time employment were £352 compared to £317 for poor readers. Splitting the hourly income distribution into quartiles, the economic advantages associated with competent reading was abundantly clear: 25 per cent of competent readers and 46 per cent of poor readers had an hourly wage in the bottom quartile of earnings, showing the increased number of hours poor readers would have to work to earn a comparable income.

\section{Young women}

Among women fewer competent than poor readers had entered employment when they were still 16 (35\%-48\%). Between age 16 and 34, competent readers spent an average of 27 months more in full-time employment (30 months in any employment) and 10 months more in full-time education when compared to poor readers by age 10 . Conversely, poor readers had experienced six months more unemployment and 22 months more full-time home-care. Patterns of exiting the workforce to (mainly) look after children are shown in 
(a)

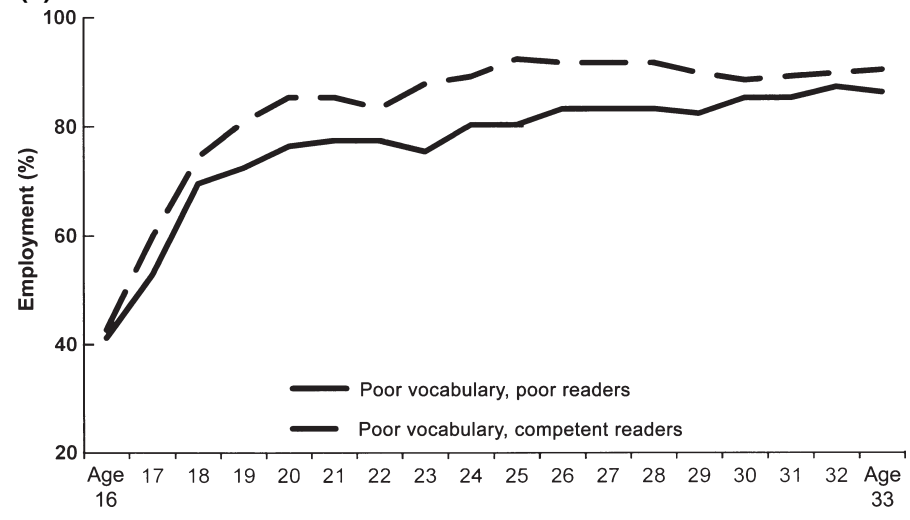

(b)

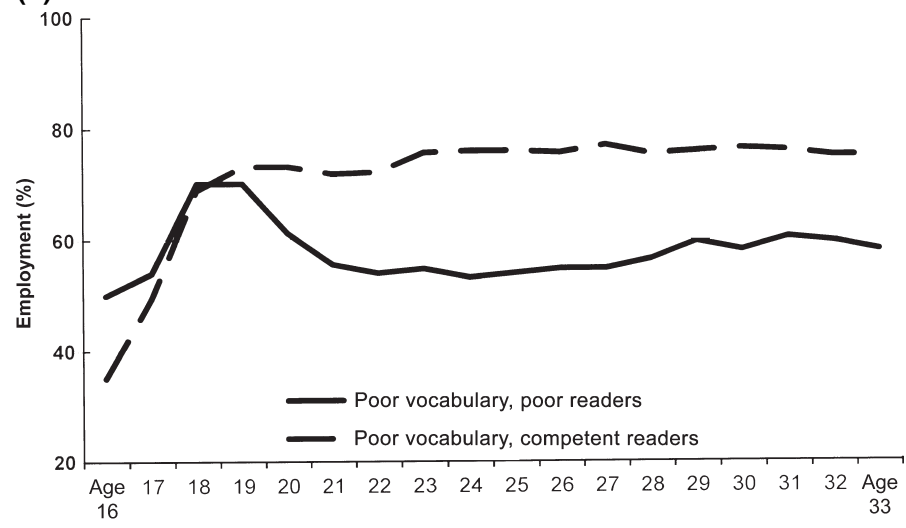

Figure 1: (a) Per cent in full-time employment January 1986-December 2003: men with poor vocabulary at age 5 and competent versus poor reading at age 10. (b) Per cent in paid employment January 1986-December 2003: women with poor vocabulary at age 5 and competent versus poor reading at age 10 .

Figure 1(b). In each year from 1988 onwards (i.e. since age 18), more competent readers were in paid employment. Between age 21 and 29, three-quarters of competent readers and just over half of poor readers were in paid employment. This 'gap' had not substantially closed by 2003 (age 33-34). Competent readers seemed better able to combine work and family life, probably reflecting that their jobs were more secure, offered maternity pay and better remuneration to accommodate childcare responsibilities.

At age 34, 40 per cent of poor readers were not engaged in education, employment or training (NEET) and 27 per cent were part of a non-working household. Figures for competent readers were 27 per cent and 11 per cent respectively.

Among those who were employed, 37 per cent of competent readers held a professional or managerial occupation, compared to 21 per cent of poor readers. Around a third of women held skilled nonmanual jobs, but whereas 18 per cent of competent readers were in partly or unskilled manual jobs, and this increased to 36 per cent among poor readers. Although more women than men were low earners, average weekly net earnings among women who 
Table 4: Employment characteristics of adults who had poor vocabulary at age 5 who were competent readers (CR) versus poor readers (PR) at age 10

\begin{tabular}{|c|c|c|c|c|c|c|c|c|}
\hline & \multicolumn{4}{|l|}{ Men } & \multicolumn{4}{|c|}{ Women } \\
\hline & $\mathrm{CR}$ & $N$ & PR & $N$ & CR & $N$ & PR & $N$ \\
\hline \multicolumn{9}{|l|}{ Employment $^{\mathrm{a}}$} \\
\hline \% Employed (16) & $46^{\mathrm{ns}}$ & 165 & 48 & 111 & $35^{* *}$ & 325 & 48 & 139 \\
\hline \% Employed full-time & $88^{\text {ns }}$ & 165 & 82 & 111 & $41^{*}$ & 325 & 31 & 139 \\
\hline \% Employed part-time & & & & & $31^{\mathrm{ns}}$ & 325 & 30 & 139 \\
\hline$\%$ Unemployed & $6^{\mathrm{ns}}$ & 165 & 6 & 111 & $1^{*}$ & 325 & 5 & 139 \\
\hline$\%$ full-time home-care & & & & & $22^{\mathrm{ns}}$ & 325 & 30 & 139 \\
\hline$\%$ NEET & $12^{\mathrm{ns}}$ & 165 & 16 & 111 & $27^{* * *}$ & 325 & 40 & 139 \\
\hline$\%$ Non-manual job & $46^{* * *}$ & 145 & 25 & 93 & $75^{* *}$ & 236 & 54 & 83 \\
\hline \% Prof/managerial job & $32^{* *}$ & 145 & 16 & 93 & $37^{* *}$ & 236 & 21 & 83 \\
\hline$\%$ Partly/unskilled job & $16^{* * *}$ & 145 & 31 & 93 & $18^{* *}$ & 236 & 36 & 83 \\
\hline Average weekly net earnings (£) (full-time employed) & $352^{*}$ & 124 & 326 & 74 & $290^{* *}$ & 124 & 218 & 42 \\
\hline $\begin{array}{l}\text { \% Hourly net earnings in bottom quartile } \\
\text { (full-time employed) }\end{array}$ & $25^{*}$ & 124 & 46 & 74 & $27^{* *}$ & 124 & 66 & 42 \\
\hline$\%$ part of non-working household & 11 & 165 & 15 & 111 & $11^{* * *}$ & 325 & 27 & 139 \\
\hline \multicolumn{9}{|l|}{ Employment histories 16-34 } \\
\hline Mean months in $\mathrm{f} / \mathrm{t}$ employment & $175^{* * *}$ & 165 & 156 & 111 & $116^{* * * *}$ & 325 & 92 & 139 \\
\hline Mean months in employment & $179^{*}$ & 165 & 164 & 111 & $152^{* * * *}$ & 325 & 125 & 139 \\
\hline Mean months unemployed & $10^{*}$ & 165 & 19 & 111 & $3^{*}$ & 325 & 9 & 139 \\
\hline Mean months on a training course & $4^{* * * *}$ & 165 & 12 & 111 & $3^{*}$ & 325 & 5 & 139 \\
\hline Mean months in education & $17^{* * * *}$ & 165 & 7 & 111 & $20^{* * * *}$ & 325 & 10 & 139 \\
\hline Mean months in home-care & 0 & 165 & 0 & 111 & $33^{* * * *}$ & 325 & 55 & 139 \\
\hline
\end{tabular}

Statistical significance: ${ }^{* * *} P<0.001,{ }^{* *} P<0.01,{ }^{*} P<0.05$, ${ }^{\text {ns }}$ not significant.

${ }^{a}$ Data collected age 34 unless stated.

worked full-time still differed widely by reading competence at age 10: competent readers earned 33 per cent more than poor readers (£290-£218). Hourly net wages revealed an even starker picture: 27 per cent of competent readers had an hourly net income in the bottom quartile of earnings compared to a huge 66 per cent of poor readers. (Differences were almost identical when part-time work was included.) As for men, this lower remuneration would mean that female poor readers would have to work increased hours to earn a comparable income.

\section{Discussion}

Findings suggest that the majority of children with poor receptive vocabulary at age 5 are developing into competent readers by age 10. It appears that school-age children receive vital stimulation from their family and school environment, which allows them to learn and develop their skills. Yet not all children benefit, and the most disadvantaged are left behind, especially those exposed to poor schooling.

In interpreting the findings, it has to be considered that the results only show significant associations with childhood reading performance and not the consequences of competent or poor reading. Socioeconomic disadvantage is associated with poor early vocabulary and later reading problems and the educational support given to children at home and the learning environment at school are crucially important. Children who become competent readers were more likely to be read to by parents, less likely to have a parent or sibling with reading difficulties and more likely to have parents interested in their educational 
progress. They were also less likely to have attended a school within a disadvantaged catchment area and far less likely to have been in a class where a greater than average number of children received remedial reading help. This suggests that the resources within a classroom might become too stretched to be able to adequately assist all children. Although the study is based on children entering school in the mid-1970s, the findings have relevance for today, especially given persisting social inequalities in educational opportunities. Educational inclusion can only be successful if all children receive the support they need to reach their full potential from the earliest opportunity - whatever end of the ability scale they happen to fall. In the schools of today, teachers cannot successfully meet the needs of all children without the invaluable help provided by teaching assistants to children with learning or educational support needs.

The study furthermore provides evidence of the long-term consequences of reading attainment on employment. By using the full scope of longitudinal data, we have been able to compare experiences of children identified with poor receptive language at age 5 who became competent or poor readers by age 10. Results indicate that competent readers had, on average, a less challenging journey into early adulthood than poor readers. Furthermore, better readers were in more highly paid employment and had fewer periods of unemployment, and thus will have contributed significantly via their taxes to the benefit of society. Poor readers, in contrast, have continued to struggle, demonstrating the long-term costs of persisting reading difficulty, making a clear case for intervention.

The findings suggest that children with poor language development grew up in a family environment characterised by reduced levels of material and human resources. These are areas that policy can continue to address. Efforts to raise the reading skills of young children should not only be targeted at the child, but at the wider social context, the 'literacy environment' in which vocabulary and reading development takes place (High and others, 1999, 2000; Klass, 2002). This must include an understanding of the degree to which access to a literacy-rich environment is promoted and facilitated. Parents of poor readers may be less likely to have qualifications or an extended education, but they can be encouraged to be interested in their child's education - and their own - with family learning programmes. If parents are supportive of their child's learning, poor family and school socioeconomic characteristics will impact less negatively on a child improving their reading. However, emphasis must not only rest on the parent. Experiences in school can counterbalance and support children in relatively disadvantaged families. Priority should be given to schools whose intake is largely from more socially disadvantaged groups, where resources within schools are most stretched.

Research has shown that most variation in adult literacy scores is explained by the family situation and set of experiences that occur up until age 10 or 11 (Bynner and Steedman, 1995; Parsons and Bynner, 1998, 2007). For policy to impact the most on reducing disadvantaged experiences associated with poor reading, it needs to continue to target poor skills development of children within the wider social context when they first present - during pre-school and primary school. However, interventions must not be short-lived. No child should be allowed to progress to the more complex environment that is secondary school without ensuring they are equipped with competent, age-appropriate reading skills. The long-term social and economic costs of failing these children fall on individuals and wider society. The case for early intervention is clear to see. 


\section{Acknowledgements}

The authors acknowledge the support of the Economic and Social Science Research Council (RES-000-22-1748) in the preparation of this manuscript.

\section{Notes}

1 'High' is used to represent scores $1+$ standard deviation above the average (mean) score.

2 The average number in a class among this sample of children was four.

\section{References}

Arriaga RJ, Fenson L, Cronan T, Pethick SJ. 1998. Scores on the MacArthur Communicative Development Inventory of children from and low- and middle-income families. Applied Psycholinguistics 19: 209-223.

Berlin G, Sum A. 1988. Toward a More Perfect Union: Basic Skills, Poor Families and Our Economic Future. Ford Foundation, Project on Social Welfare and the American Future: New York.

Brimer MA, Dunn LM. 1962. English Picture Vocabulary Test. Education Evaluation Enterprises: Bristol.

Brooks G (Cartographer). 2002. What Works for Children With Literacy Difficulties? The Effectiveness of Intervention Schemes. Research report 380. Department for Education and Skills: London.

Brooks-Gunn J, Duncan GJ. 1997. The effects of poverty on children. Children and Poverty 7: 55-71.

Bynner J, Parsons S. 2006. New Light on Literacy and Numeracy: Results of the Literacy and Numeracy Assessment in the Age 34 Follow-up of the 1970 British Cohort Study (BCS70). National Research and Development Centre for Adult Literacy and Numeracy: London.

Bynner J, Steedman J. 1995. Difficulties With Basic Skills. The Basic Skills Agency: London.

De Coulon A, Meschi E, Vignoles A. 2008. Parents' Basic Skills and Their Children's Test Scores. National Research and Development Centre for Adult Literacy and Numeracy: London.

DeWalt DA, Berkman ND, Sheridan S, Lohr KN, Pignone MP. 2004. Literacy and health outcomes: a systematic review of the literature. Journal of General Internal Medicine 19: 1228-1239.

Duncan GJ, Brooks-Gunn J. 1997. Consequences of Growing up Poor. Russell Sage Foundation Press: New York.

Elliott J, Shepherd P. 2006. Cohort profile of the 1970 British Birth Cohort (BCS70). International Journal of Epidemiology 35: 836-843.

Essen J, Fogelman K, Head J. 1978. Childhood housing experiences. Childcare, Health and Development, 4: 41-58.

Evans GW. 2006. Child development and the physical environment. Annual Review of Psychology 57: 423-451.

Evans GW, Lepore SJ, Shejwal BR, Palsane MN. 1998. Chronic residential crowding and children's well being: an ecological perspective. Child Development, 69: 1514-1523.

Feagans L, Farran DC (eds). 1982. The Language of Children Reared in Poverty: Implications for Evaluation and Intervention. Academic Press: New York.

Gottfried AW. 1984. Home Environment and Early Cognitive Development. Academic Press: New York.

Grinyer J. 2006. Literacy, Numeracy and the Labour Market: Further Analysis of the Skills for Life Survey. Department for Education and Skills: London.

High P, Hopmann M, LaGasse L, Sege R, Moran J, Guiterrez C, Becker S. 1999. Child Centered Literacy Orientation: a form of social capital? Pediatrics 103: 1-7.

High P, LaGasse L, Becker S, Ahlgren I, Gardner A. 2000. Literacy promotion in primary care pediatrics: can we make a difference? Pediatrics 105: 927-934.

Hodder M, Stoughton TW. 1979. The Shortened Edinburgh Reading Test. Hodder and Stoughton Educational Ltd: Kent. 
Hoff E. 2003. The specificity of environmental influence: socio-economic status affects early vocabulary development via maternal speech. Child Development 74: 1368-1378.

Hopman RM, Gerristen FM, Talsma P. 1988. Socioeconomic status and gender differences in language development of children aged 3 to 6 years. Pedagogische Studien 65: 437-450.

Klass P. 2002. Pediatrics by the book: pediatricians and literacy promotion. Pediatrics 110: 989-995.

McLoyd VC. 1998. Socioeconomic disadvantage and child development. American Psychologist 53: 185-204.

Mendelsohn AL, Mogilner LN, Dreyer BP. 2001. The impact of a clinic-based literacy intervention on language development in inner-city preschool children. Pediatrics 107: 130-134.

Osborn AF, Butler NR, Morris AC. 1984. The Social Life of Britain's Five-Year-Olds: A Report of the Child Health and Education Study. Routledge \& Kegan Paul: London.

Parsons S, Bynner J. 1998. Influences on Adult Basic Skills. The Basic Skills Agency: London.

Parsons S, Bynner J. 2007. Illuminating Disadvantage. National Research and Development Centre for adult literacy and numeracy: London.

Raikes HH, Raikes HA, Pan BA, Luze G, Tamis-LeMonda CS, Rodriguez ET, Brooks-Gunn J, Constantine J, Tarullo LB 2006. Mother-child bookreading in low-income families: correlates and outcomes during the first three years of life. Child Development 77: 924-953.

Rutter M, Tizard J, Whitmore K. 1970. Education, Health and Behaviour. Longmans: London.

Sammons P, Elliot K, Sylva K, Melhuish E, Siraj-Blatchford I, Taggart B. 2004. The impact of pre-school on young children's cognitive attainments at entry to reception. British Educational Research Journal 30: 691-713.

Weigel DJ, Martin SS, Bennett KK. 2006. Contributions of the home literacy environment to preschoolaged children's emerging literacy and language skills. Early Child Development and Care, 176: 357-378.

Yamomoto M. 1990. Birth order, gender differences and language development in modern Japanese pre-school children. Psychologia: an International School of Psychology in the Orient, 33: 185-219.

*Correspondence to: Samantha Parsons, Centre for Longitudinal Studies, Institute of Education, University of London, 20 Bedford Way, London, WC, UK. Tel.: 0207612 6882; Fax: 0207612 6671. E-mail: s.parsons@ioe.ac.uk

Accepted for publication 16 September 2009 